\title{
The response of Pinus species to ozone uptake in different climate regions of Europe
}

\author{
Svetlana Bičárová ${ }^{1 *}$, Anumol Shashikumar ${ }^{2}$, Laurence Dalstein- Richier ${ }^{2}$, \\ Veronika Lukasová ${ }^{1}$, Katarína Adamčíková ${ }^{3}$, Hana Pavlendová 4 , Zuzana Sitková ${ }^{4}$, \\ Anna Buchholcerová ${ }^{1}$, Dušan Bilčík ${ }^{1}$ \\ ${ }^{1}$ Earth Science Institute of the Slovak Academy of Sciences, Stará Lesná, SK - 05960 Tatranská Lomnica, Slovak Republic \\ ${ }^{2}$ GIEFS (Groupe International d'Études des Forêts Sud-Européennes), 69 avenue des Hespérides, FR - 06300, Nice, France \\ ${ }^{3}$ Institute of Forest Ecology SAS Zvolen, Department of Plant Pathology and Mycology, Akademická 2, SK-94901 Nitra, \\ Slovak Republic \\ ${ }^{4}$ National Forest Centre - Forest Research Institute Zvolen, T. G. Masaryka 2175/22, SK - 96001 Zvolen, Slovak Republic
}

\begin{abstract}
This study is focused on the research of selected Pinus species exposed to high ozone concentrations in the mountain environment. We noticed different values of modelled ozone doses (MOD) up-taken by Mountain pine (Pinus mugo Turra) in the High Tatra Mts (SK-HTMts) and Swiss stone pine (Pinus cembra L.) in the Alpes-Mercantour (FR-AlpMar) during the growing season 2019. The MOD values were obtained by multiplicative DO3SE model, while we also tested a new approach based on modification of input ozone data. The MOD values were obtained by multiplicative DO3SE model, while we also tested a new approach based on modification of input ozone data. Testing has shown that ozone input based on passive sampling may be used in MOD modelling for sites situated in the subalpine zone where the operation of active monitors is limited. . Presented results confirmed the assumption regarding stomatal ozone flux reduction due to the occurrence of soil drought in hot and dry summer weather typical for the Mediterranean climate region. Despite the limitation of stomatal flux, foliar ozone specific injury on two years needles of $P$. cembra was substantially higher in comparison to the incidence of ozone injury symptoms observed on two years needles of $P$. mugo in SK-HTMts. It may suggest low phytotoxicity of given MOD or efficient resistance of $P$. mugo against oxidative stress. In addition, the visible injury index (VINX) covering the broad effect of biotic and abiotic harmful agents was appraised on P. mugo. Percentage of affected surface indicated moderate deterioration of needle injury at the end of the growing season, particularly due to traces of mechanical damage.
\end{abstract}

Key words: Modelled Ozone Dose (MOD); Visible Injury Index (VINX); passive $\mathrm{O}_{3}$ sampling; soil humidity; mountain environment

Editor: Peter Fleischer

\section{Introduction}

Air quality is still a serious problem in contemporary society. Recent geographical models that provide transparent information about the world's (WAQI 2019) or European (EAQI 2019) air pollution highlights the Air Quality Index (AQI) based on the measurement of key pollutants in the ambient air including ozone concentration $\left(\mathrm{O}_{3}\right)$. The abundant $\mathrm{O}_{3}$ formation manifesting by AQI increase may lead to an adverse effect on human health (Analitis et al. 2018; Orru et al. 2019) and vegetation (Bendáková \& Hůnová 2015; Feng et al. 2017; Gong et al. 2020). The risk of exposure of forest area to ozone is estimated by the AOT40 index (Directive
2008/50/EC) derived from the $\mathrm{O}_{3}$ concentration measured in the ground level of the atmosphere. However, scientific evidence (Ashmore et al. 2004; Matyssek et al. 2007; Sicard et al. 2016) has suggested that AOT40based critical levels for vegetation should be replaced by stomatal flux-based critical levels that reflect the amount of ozone transported into the leaves (Mills et al. 2011). The accumulated stomatal flux over a specified time interval is represented by the modelled parameter of PODY (the Phytotoxic Ozone Dose over a threshold flux of $\mathrm{Y}\left(\mathrm{nmol} \mathrm{m}{ }^{-2} \mathrm{PLA} \mathrm{s}^{-1}\right)$ where Y means a detoxification threshold and PLA is the projected leaf area. Expert judgement was used to set $Y=1 \mathrm{nmol} \mathrm{m}^{-2} \mathrm{PLA} \mathrm{s}^{-1}$ based 
on observation of $\mathrm{O}_{3}$ sensitivity under controlled conditions (Dizengremel et al. 2013). The threshold Y below which it is assumed that any $\mathrm{O}_{3}$ molecule absorbed by the plant will be detoxified may be due to species specificity and the difference in the real environment. The high sensitive conifers are Pinus species (Dalstein \& Vas 2005), however different visible $\mathrm{O}_{3}$ injury response may be expected under natural conditions due to differences in $\mathrm{O}_{3}$ sensitivity controlled by genotype and micro site conditions of growth, exposure, and $\mathrm{O}_{3}$ flux (Coulston et al. 2003; Nunn et al. 2007; Braun et al. 2014). Considering that, the goal of this work is to specify the phytotoxic $\mathrm{O}_{3}$ effect on mountain timberline tree species using the modelled value of ozone dose (MOD), regardless of "Y", against visible injury index (VINX) that traces biotic and abiotic damage including visible $\mathrm{O}_{3}$ injury.

Mountain timberline is exposed to relatively high $\mathrm{O}_{3}$ concentration (Bytnerowicz et al. 2004; Hůnová et al. 2010; Bičárová et al. 2019) produced by photochemical transformation of precursors from both anthropogenic and biogenic sources with the addition of large-transmission transport of polluted air masses. Monitoring of $\mathrm{O}_{3}$ pollution in complex terrain is commonly performed by passive sensors, while modelling of PODY requires continuous measurement of $\mathrm{O}_{3}$ concentration in hourly step. Therefore we consider it beneficial to introduce a new approach consists of the modification of MOD calculation incorporating $\mathrm{O}_{3}$ data from passive samplers. Along with ozone, environmental conditions play a key role in stomatal $\mathrm{O}_{3}$ uptake and climate affects the mountain ecosystems in a complex way (Zapletal et al. 2012; Kopáček et al. 2017; Fleischer et al. 2017; Mezei et al. 2017). In this context, we investigated the effect of environmental factors on stomatal $\mathrm{O}_{3}$ flux covering two different mountain bioclimatic regions of Europe such as (1) the High Tatra Mts (SK-HTMts) in the Western Carpathians with a temperate climate and (2) the AlpesMercantour (FR-AlpMar) in the Alpes-Maritimes with a Mediterranean climate.

The objectives of this study were: (i) to model ozone dose (MOD) for sensitive mountain conifers Swiss stone pine (Pinus cembra L.) and Mountain pine (Pinus mugo Turra) during the growing season 2019; (ii) to appraise the role of environmental factors $\operatorname{in}_{3}$ uptakes under contrasting climate conditions; (iii) to test the use of passive $\mathrm{O}_{3}$ sampler measurements in MOD modelling; and (iv) to analyse the relationship between MOD results and field observation of visual injury for $P$. mugo in SK-HTMts and P. cembra in FR-AlpMar.

\section{Material and methods}

\subsection{Study area}

The study area (Fig. 1) includes a subalpine zone of two different climate regions situated in the Tatra National park (SK-HTMts) and in the Mercantour National
Park (FR-AlpMar). The territory of the High Tatra Mts. belongs to the continental climate zone characterized by cold winters, mildly warm, and wet summers. Based on climate data obtained at Skalnaté Pleso Observatory (SPO: 49 $11^{\prime} 21^{\prime \prime} \mathrm{N} ; 20^{\circ} 14^{\prime} 02^{\prime \prime} \mathrm{E}$; $1,778 \mathrm{~m}$ a.s.l.) since 1943 , the mean temperature of the coldest month (February) is $-5.6^{\circ} \mathrm{C}$ and mean temperature in two summer months (July, August) is close above $10^{\circ} \mathrm{C}$. Long-term (1943-2019) mean annual air temperature is $2.2^{\circ} \mathrm{C}$. The annual mean of $2.8^{\circ} \mathrm{C}$ confirms climate warming during the last decades (1991-2019). Precipitation is concentrated mostly in the warmer months from May to October, the monthly maximum is in July and achieves $221 \mathrm{~mm}$ on average (1943-2019). The most vulnerable vegetation in the subalpine zone is $P$. mugo (Bičárová et al. 2019) that reaches the highest coverage at 1,450 $\mathrm{m}$ a.s.l. and decreases with increasing altitude, where forests become sparser. Positions around 2,100 $\mathrm{m}$ a.s.l. is occupied by individual shrubs with very low density. We selected 10 monitoring sites in the vicinity of SPO (Fig. 2) for inspection of visible injury on P. mugo during vegetation season 2019. In order to model $\mathrm{O}_{3}$ fluxes, the $\mathrm{O}_{3}$ concentration, and environmental parameters were considered for the site SPO where both, meteorological and $\mathrm{O}_{3}$ measurements are carried out.

FR-AlpMar within Alpes-Maritimes County is renowned for its hot temperatures and pleasant climate throughout the year. Although the weather is sunny and dry during the summer months, it can be quite cool and fresh in the mountains. In the Mercantour National Park, less than $70 \mathrm{~km}$ from the Mediterranean Riviera, the summits of Mercantour culminate up to more than $3,000 \mathrm{~m}$ of altitude leading to a multitude of bioclimatic floors. The climate of subalpine zone FR-AlpMar represented by sites situated along Route du Col de Salèse (RCS: $44^{\circ} 07^{\prime} 42^{\prime \prime} \mathrm{N}, 7^{\circ} 15^{\prime} 14^{\prime \prime} \mathrm{E}, 1,790 \mathrm{~m}$ a.s.l.) is hot with dry summers and mild, wet winters. Climate patterns based on 30 years of hourly weather model simulations (Meteoblue 2019) available for RCS site show that a period of mean temperature above $10^{\circ} \mathrm{C}$ lasts from June to September with a peak of $15^{\circ} \mathrm{C}$ in July and August. The mean temperature of the coldest month (January) is around $-2.5^{\circ} \mathrm{C}$. Precipitation amount increases in the spring months (April and May) when the monthly total is about $300 \mathrm{~mm}$. In summer months (June, July, August) precipitation amount decreases deeply under $200 \mathrm{~mm}$. Studies have shown (Dalstein et al. 2005; Sicard et al. 2011) that many areas in the south of France, and more particularly the rural alpine Mediterranean area of the Mercantour National Park, may be affected by considerable quantities of ozone that originates from regional road traffic combined with the strong hot season of the Mediterranean climate, along the French Riviera, and on the Pô River plain in Italy. The regional forests have thus become the primary victims of the photochemical pollution given off by metropolitan Nice areas and their associated automobile traffic. 


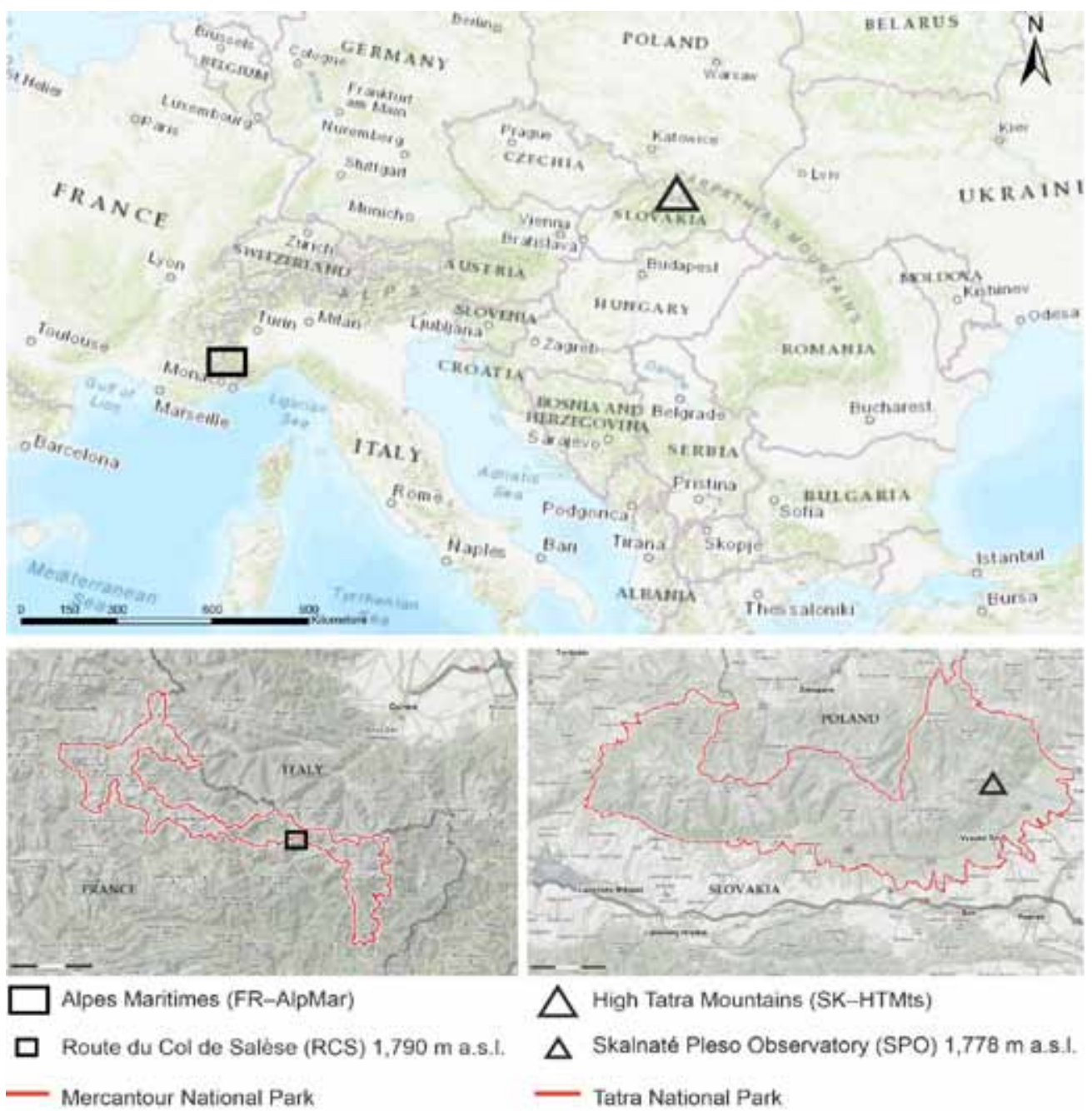

Fig. 1. The geographical position of the Tatra National Park (SK-HTMts) in the Carpathian mountain range and the Mercantour National Park in the Alpes-Maritimes region (FR-AlpMar) including selected sites: SPO - Skalnaté Pleso Observatory; RCS Route du Col de Salèse.

\subsection{Ozone dose modelling}

Model simulation of MOD up-taken by Pinus species was performed by the multiplicative deposition model $\mathrm{DO}_{3} \mathrm{SE}$ (Büker et al. 2012). In this work, the model output of phytotoxic ozone dose without threshold limitation $(\mathrm{Y}=0)$ i.e. POD0 was considered identical to MOD. As demonstrates Eq. 1, $\mathrm{MOD}\left(\mathrm{mmol} \mathrm{O}_{3} \mathrm{~m}^{-2} \mathrm{PLA}\right)$ represents the amount of $\mathrm{O}_{3}$ taken up by the vegetation via open stomata as stomatal ozone flux $\left(\mathrm{F}_{\mathrm{st}}\right.$ in $\left.\mathrm{nmol} \mathrm{m} \mathrm{m}^{-2} \mathrm{~s}^{-1}\right)$ aggregated over the period between the start (SGS) and end (EGS) of the growing season [Eq. 1]. We considered the length of

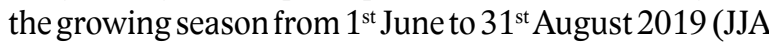
2019) that cover the summer season when the intensity of the physiological process of mountain vegetation is the highest.

$$
M O D=\sum_{S G S}^{E G S}\left[F_{S t} *\left(3,600 / 10^{6}\right)\right]
$$

$\mathrm{F}_{\mathrm{st}}$ stands for the rate of passage of $\mathrm{O}_{3}$ entering through the stomata of a leaf and is defined (Eq. 2) by stomatal conductance $\left(\mathrm{G}_{\mathrm{sto}}\right.$ in $\left.\mathrm{mmol} \mathrm{O}_{3} \mathrm{~m}^{-2} \mathrm{~s}^{-1}\right)$ and concentration of $\mathrm{O}_{3} \mathrm{c}\left(\mathrm{z}_{1}\right)$ in nmol $\left.\mathrm{m}^{-3}\right)$ at the top of the canopy measured in the tree height $\left(\mathrm{z}_{1}\right)$

$F_{s t}=F_{s t o} * c\left(z_{1}\right) * R_{s t}=G_{\text {max }} * f_{E N V I} * c\left(z_{1}\right) * R_{s t}$

where $\mathrm{R}_{\mathrm{st}}$ is a resistance factor reflecting the quasi-laminar resistance and leaf surface resistance $\left(\mathrm{s} \mathrm{m}^{-1}\right)$ on $\mathrm{F}_{\mathrm{st}}$.

Key parameter for $\mathrm{G}_{\text {sto }}$ calculation is maximal stomatal conductance $\left(\mathrm{G}_{\max }\right.$ in $\left.\mathrm{mmol} \mathrm{O}_{3} \mathrm{~m}^{-2} \mathrm{~s}^{-1}\right)$ that is species specific parameter optional in model assignment or derived from experimental measurements. Model values of $G_{\text {sto }}$ correspond to $G_{\max }$ limited by environmental factors $\left(\mathrm{f}_{\mathrm{ENV}}\right)$. The effects of $\mathrm{f}_{\mathrm{ENVI}}$ on $\mathrm{G}_{\max }$ [Eq. 3] including meteorological and site conditions such as air temperature $\left(\mathrm{f}_{\text {temp }}\right)$, vapour pressure deficit $\left(\mathrm{f}_{\mathrm{VPD}}\right)$, solar radiation or light $\left(\mathrm{f}_{\text {light }}\right)$, soil water potential $\left(\mathrm{f}_{\mathrm{SWP}}\right)$, plant phenol$\operatorname{ogy}\left(\mathrm{f}_{\text {phen }}\right)$, and $\mathrm{O}_{3}$ concentration $\left(\mathrm{f}_{\mathrm{O} 3}\right)$.

$$
\begin{gathered}
f_{E N V I}=\left[\min \left(f_{\text {phen }}, f_{O_{3}}\right)\right] * f_{\text {light }} * \\
\max \left\{f_{\min },\left(f_{\text {temp }} * f_{V P D} * f_{\text {SWP }}\right)\right\}
\end{gathered}
$$


Generally, there is no limitation of stomatal conductance associated with the leaf development stage of conifer species (i.e. $\mathrm{f}_{\text {phen }}=1$ ). We also considered $\mathrm{f}_{\mathrm{O} 3}=1$ because stomatal $\mathrm{O}_{3}$ flux is driven particularly by air temperature defined according to the $\mathrm{f}_{\text {temp }}$ function (ICP, 2017).

The preset, built inversion (3.0.5) of the $\mathrm{DO}_{3} \mathrm{SE}$ model (SEI, 2014) with the collection of parameters for coniferous forests and parameter $\mathrm{G}_{\max }\left(110 \mathrm{mmol} \mathrm{O}_{3} \mathrm{~m}^{-2} \mathrm{~s}^{-1}\right)$ for $P$. mugo obtained from field experiments (Bičárová et al. 2019) were used. Selected meteorological data allowed for specification of the environmental functions associated with air temperature [Eq.4], vapour pressure deficit [Eq. 5], and irradiance radiation and light [Eq. 6]:

$$
\begin{aligned}
& f_{\text {temp }}=\max \left\{f_{\min },\left[\left(\frac{A T-T_{\min }}{T_{\text {opt }}-T_{\min }}\right)\right.\right. \\
& \text { *( } \left.\left.\left(\frac{T_{\max }-T_{o p t}}{T_{o p t}-T_{\min }}\right)\right]\left(\frac{T_{\max }-T_{o p t}}{T_{o p t}-T_{\min }}\right)\right) \\
& f_{V P D}=\min \left\{1, \max \left[f _ { \operatorname { m i n } } \left(\left(1-f_{\min }\right)\right.\right.\right. \\
& \text { *( } \left.\left.\left.\left(\frac{V P D_{\min }-V P D}{V P D_{\min }-V P D_{\max }}\right)\right)+f_{\min }\right]\right\} \\
& f_{\text {light }}=1-E X P\left(\left(- \text { light }_{a}\right) * P F D\right)
\end{aligned}
$$

where AT is measured air temperature $\left({ }^{\circ} \mathrm{C}\right)$; VPD is vapour pressure deficit calculated on base of measurement of air temperature and relative air humidity $(\mathrm{kPa})$; PFD represents the photosynthetic photon flux density in units of $\mu \mathrm{mol} \mathrm{m}{ }^{-2} \mathrm{~s}^{-1}$ i.e., photosynthetically-active radiation (PAR) derived from measurement of global solar radiation $\mathrm{R}\left(\mathrm{W} \mathrm{m}^{-2}\right)$. These variables are completed with the species-specific parameters $\mathrm{f}_{\text {min }}(0.1), \mathrm{T}_{\text {min }}\left(1^{\circ} \mathrm{C}\right)$, $\mathrm{T}_{\text {opt }}\left(18^{\circ} \mathrm{C}\right), \mathrm{T}_{\max }\left(36^{\circ} \mathrm{C}\right), \mathrm{VPD}_{\text {min }}(-3.3 \mathrm{kPa}), \mathrm{VPD}_{\text {max }}$ $(0.6 \mathrm{kPa})$, and light $\mathrm{a}_{\mathrm{a}}(0.008)$. The functions $\mathrm{f}_{\text {temp }}, \mathrm{f}_{\mathrm{VPD}}$, and $\mathrm{f}_{\text {light }}$ are expressed in relative terms (i.e., they accept values between 0 and 1 as a proportion of $\mathrm{G}_{\max }$ ).

\subsection{Measured input data}

Meteorological variables at SPO site were continuously monitored in hourly step using the measurement system based on a PROlog ultra-low power datalogger (Physicus, SK) connected with the following sensors: (AT) temperature probe with platinum resistance thermometers Pt100 for air temperature (at $2 \mathrm{~m}$ above the surface); (RH) Prove-HumiAir 9 for relative air humidity; (R) Pyranometer CMP6 (Kipp and Zonen) for global solar radiation; (WS) Wind Transmitter Compact (Thies Clima) for wind speed, (P) PressAir sensor for air pressure, and (Ppt) Rain Gauge (MR3H - Meteoservice CZ) for precipitation.
Meteorological input data at RCS site were derived from measurements of Meteo-France in region ProvenceAlpes-Côte d'Azur by approximation method. Air temperature $\left(\mathrm{AT},{ }^{\circ} \mathrm{C}\right)$ and relative humidity $(\mathrm{RH}, \%)$ values were derived by linear interpolation with respect to altitudinal gradient. VPD $(\mathrm{kPa})$ for a given AT and RH was calculated by a specific formula for saturated and actual vapour pressure. Precipitation (Ppt, $\mathrm{mm}$ ) and wind speed (WS, $\mathrm{m} \mathrm{s}^{-1}$ ) data were derived from the nearest weather stations with respect to altitude zones. Air pressure (P, $\mathrm{kPa}$ ) calculation used the barometric formula for given AT and altitude. Solar global radiation $\left(\mathrm{R}, \mathrm{W} \mathrm{m}^{-2}\right)$ corresponded to measurement at the nearest weather stations.

Soil moisture data were obtained by modelling soil water potential (SWP in MPa), useful forn specifying the $\mathrm{f}_{\text {sWP }}$ function [Eq. 7].

$$
\begin{aligned}
& f_{S W P}= \min \left\{1,\left\{f _ { \text { min } } \left(\left(1-f_{\min }\right) *\left(S W P_{\min }-S W P\right)\right.\right.\right. \\
&\left.\left.\left./\left(S W P_{\text {min }}-S W P_{\max }\right)\right)+f_{\min }\right\}\right\}
\end{aligned}
$$

The $\mathrm{f}_{\text {swP }}$ function defines the effect of soil moisture on $\mathrm{G}_{\max }$ [Eq. 2] in relative terms, similar to the aforementioned functions [Eq. 4-6] using additional threshold parameters, such as SWPmin (-1.20 MPa) and SWPmax $(-0.76 \mathrm{MPa})$. In addition, field measurement of SWP was conducted at three soil depths $(-0.1,-0.2,-0.4 \mathrm{~m})$ only at SPO site. SWP values were measured using gypsum blocks at a range up to $-1.5 \mathrm{MPa}$ (GB2, Delmhorst Instrument, U.S.A.). SWP data were stored in integrated data loggers (MicroLog SP3, EMS Brno, CZ) at 1-hour intervals. Differences between $\mathrm{f}_{\text {SwP }}$ based on measured and modelled SWP allow for verification of reliability for the soil moisture module included in the $\mathrm{DO}_{3} \mathrm{SE}$ model. This modelling approach incorporated hydraulic resistance (steady state, SS) to water flow through the plant system (Büker et al. 2012).

Measurement of $\mathrm{O}_{3}$ concentration at SPO was employed by calibrated active monitors (Thermo Electron Environmental 49C) based on the well established technique of absorption of UV light at $254 \mathrm{~nm}$. Hourly mean data were recorded in a continuous regime without major gaps throughout the year 2019. For purposes of this study, the hourly meteorological and $\mathrm{O}_{3}$ concentration data for summer months (June, July, and August) were analysed.

In FR-AlpMar, passive samplers developed in Sweden by IVL (Svenska Miljöinstitutet) were used for measurement of $\mathrm{O}_{3}$ concentration. These passive $\mathrm{O}_{3}$ sensors have the advantage of allowing large-scale monitoring of concentrations of gaseous pollutants in remote rural areas (Krupa \& Legge 2000). ThePpassive sampler was placed in the open air, not under forest cover, and was protected by a metal sheet approximately $1.8 \mathrm{~m}$ above the ground. Ionic chromatography was used to analyse the ozone concentration (IVL Laboratories Sweden). This technic was validated in 2000, accuracy was verified by 
comparing the results from the passive tube samplers with the results from the UV absorption analysers (Dalstein et al. 2001). Passive $\mathrm{O}_{3}$ sampling provides input $\mathrm{O}_{3}$ data in a monthly step that is not sufficient for standard MOD calculation. For this reason model processing was divided into two parts. In the first part, measured hourly meteorological data and theoretical $\mathrm{O}_{3}$ concentration 1 ppb were processed by the $\mathrm{DO}_{3} \mathrm{SE}$ model to obtain the theoretical $\mathrm{MOD}_{1}$. In the second part, the final MOD was calculated by multiplying $\mathrm{MOD}_{1}$ and average $\mathrm{O}_{3}$ concentration measured over the period. This procedure was applied individually for $P$. mugo (STO) and $P$. cembra (RCS). Model calculation of MOD based on continuously measured hourly values of $\mathrm{O}_{3}$ concentration and meteorological variables at SPO site were used to verify this modified approach.

\subsection{Visible injury}

Inspection of visible injury on Pinus species was primarily focused on the identification of visible ozone and visible ozone like symptoms. Chlorotic mottling is the most common symptom that can be described as yellow or light green areas of similar size without sharp borders between green and yellow zones. It frequently appears only in second-year needles, and older (ICP, 2016). Observation of visible $\mathrm{O}_{3}$ injury on $P$. cembra in FR-AlpMar at RCS plot was carried in accordance with the proven techniques for evaluation of the ozone-specific symptoms, which are described in the ICP Forests protocol (Schaub et al. 2010; Michel et al. 2014).

The thick leaves of P.cembra intercept more light at low angles of incidence than at a high angle of incidence, this has an affect on the ozone symptoms appearance (Jordan \& Smith 1993) and thus at each plots $\mathrm{O}_{3}$ injury was assessed on five adult trees well exposed to sunlight. From these trees five branches with at least 30 needles per branch were removed from the upper third part of the crown and were assessed for foliar injury based on needle age classes, the percentage of needle surface affected was scored for current year needles $(C), 1$ year old $(C+1)$, and two year old $(\mathrm{C}+2)$ needles. The observations were made by experts from the GIEFS (Groupe International d'Études des Forêts Sud-Européennes). For $P$. cembra spots or mottling were recorded during late summer from midAugust to early September a period during which the concentration of ozone is highest of the year. The ozone specific foliar injury was calculated for its mean percentage by considering needles/leaf surface affected per plot.The ambition of research on P.mugo in SK-HTMts was to provide a comprehensive evaluation of surface visible injury where we considered also other harmful agents such as fungal and viral diseases, leaf biting insects, red spider mites mentioned in ICP Vegetation Ozone Injury Recording Application (ICP, 2018). Inspection of visible injury on P. mugo in SK-HTMts was realised only on two years-old $(\mathrm{C}+2)$ needles, as these needles show pronounced injury (Bičárová et al. 2019). We selected a total of 10 monitoring sites near SPO (Fig. 2 left) including 6 sites with high tree coverage (S1-S6) and 4 sites situated at the highest position (S7-S10) of $P$. mugo belt, above 2,000 $\mathrm{m}$ a.s.l. We marked three trees at each S1-S6 and one tree at each S7-S10 site, respectively. Sample of ten twin needles from each marked tree was collected at the beginning of summer (early June) and autumn (early October) season 2019 with an aim to notice changes of visible injury influenced by ozone uptake during the growing season. In addition, we performed control observation on young seedlings located indoors, protected from external influences. Two years old $P$. mugo seedlings were obtained from Gene pool center managed by specialist forest workers of the State Forests of Tatra National Park situated at the area near SPO called Rakúske lúky (49¹2‘37“ N; 20¹9‘32“"E; 800 m a.s.l.).

The visible injury both for field and control samples were identified by specialists in visible ozone injury, fungal disease, and other forest tree damage. For this study we define the visible injury index (VINX, Eq. 8) covering different harmful agents (ICP, 2018): a) fungi diseases b) stinging insects c) spider mites d) ozone, and e) abioticmechanical effects (Fig. 2 right).

$$
\operatorname{VINX}(\%)=\frac{\Sigma X_{\text {score }}}{X_{\max }}
$$

where $\Sigma \mathrm{X}_{\text {score }}=\mathrm{X}_{\mathrm{a}}+\mathrm{X}_{\mathrm{b}}+\mathrm{X}_{\mathrm{c}}+\mathrm{X}_{\mathrm{d}}+\mathrm{X}_{\mathrm{e}}$ is the sum of the scores for each harmful agent $(\mathrm{a}-\mathrm{e})$. The score corresponds to the extent of injury observed on needle surface in scale from 0 (without visible injury symptoms) to 5 (damage to the entire surface of the needles) that was evaluated individually for each harmful agent. $\mathrm{X}_{\max }$ is the sum of the maximal score for each harmful agent. According to VINX value (\%), the degree of damage was classified according to the classes mentioned in Schaub et al. 2016 (Table 1) in scale from 0 (no injury) to 3 (large damage).

Table 1. Visible injury index (VINX) classification.

\begin{tabular}{lcc}
\hline Legend & VINX (\%) & Class \\
\hline No injury & $0 \%$ & 0 \\
Low & $1-5 \%$ of the surface is affected & 1 \\
Moderate & $6-50 \%$ of the surface is affected & 2 \\
Large & $51-100 \%$ of the surface is affected & 3 \\
\hline
\end{tabular}

\section{Results}

\subsection{Environmental factors and stomatal conductance}

Effect of air temperature (AT, Eq. 4), vapour pressure deficit (VPD, Eq. 5), photosynthetically-active radiation (PFD, Eq. 6), and soil water pressure (SWP, Eq. 7) on environmental factors $\left(\mathrm{f}_{\text {temp }}, \mathrm{f}_{\mathrm{vPD}}\right.$, and $\mathrm{f}_{\text {light }}$, and $\mathrm{f}_{\text {sWP }}$ ) covering JJA 2019 period illustrates Fig. 3. As expected, $\mathrm{f}_{\text {temp}}$, $\mathrm{f}_{\text {light }}$, reflect more appropriate air temperature and solar 

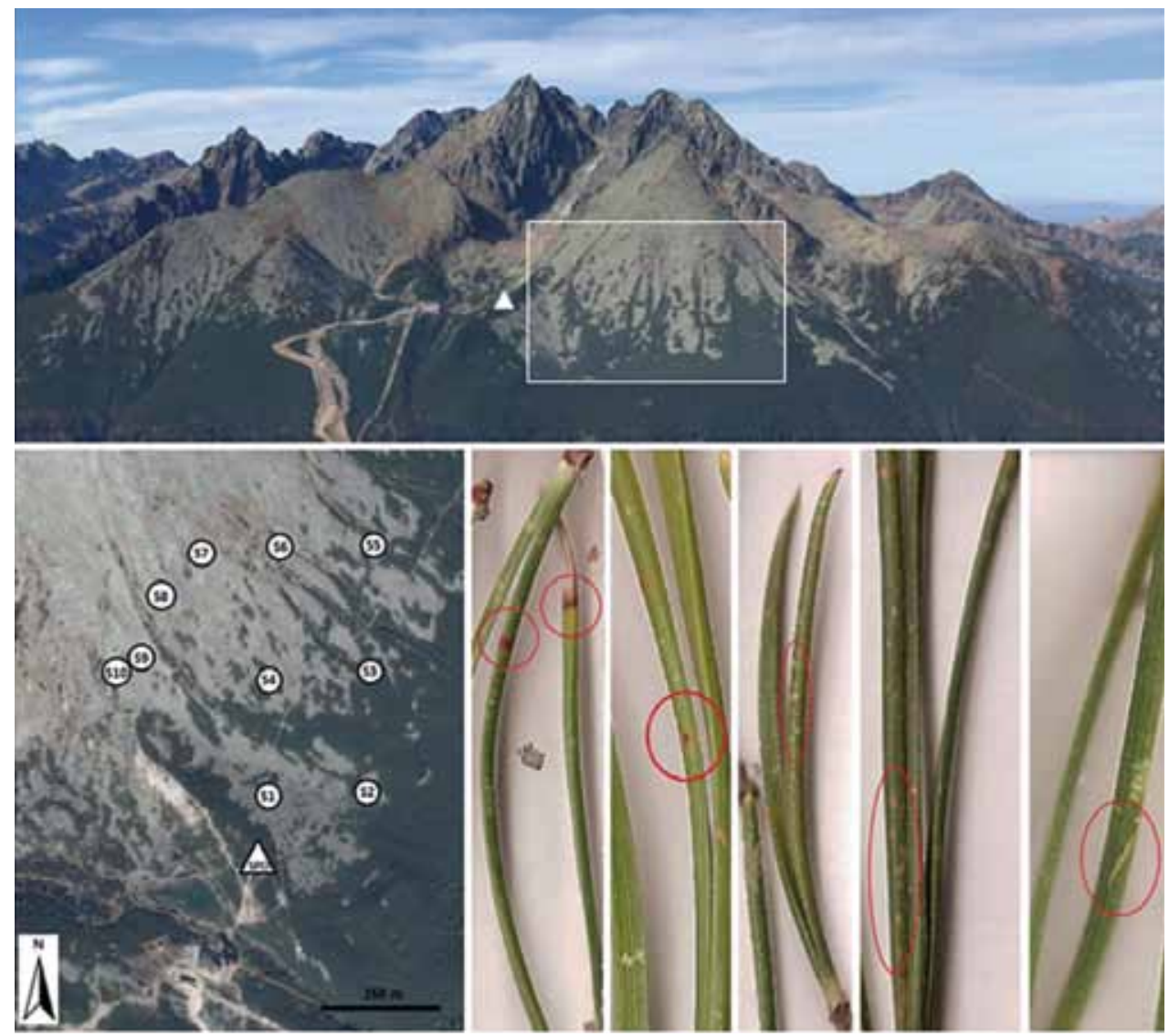

Fig. 2. The scheme of sites (S1-10) selected for collecting P. mugo needle samples in SK-HTMts (upper and lower left rectangle), triangle marks the position of Skalnaté Pleso Observatory (SPO); examples of needle damage differentiated according to the harmfull agent: a) fungi diseases b) stinging insects c) spider mites d) ozone e) abiotic-mechanical effects (lower right rectangle).

radiation conditions in Mediterranean FR-AlpMar than colder climate in SK-HTMts. Contrary, in FR-AlpMar water insufficiency in both, air and soil was more pronounced in July and August.

It is evident that $\mathrm{f}_{\text {SWP }}$ (Fig. 3) is the crucial environmental factor with a relevant influence on $G_{\text {sto }}$ in FRAlpMar (Fig. 4 right). Effect of $f_{\text {swP }}$ contributed to $G_{\text {sto }}$ limitation to minimal level up to $20 \mathrm{mmol} \mathrm{m}^{-2} \mathrm{~s}^{-1}$ during a relative long-lasting time window started at the end of June (number of the day (NOTD) $\approx 180$ ) and continuing with short interruptions until the end of summer. On the contrary, the period of $\mathrm{G}_{\text {sto }}$ limitation (close above 40 mmol m${ }^{-2} \mathrm{~s}^{-1}$ ) in SK-HTMts (Fig. 4 left) lasted only a few days in July (NOTD around 190) and was influenced primarily by cold wave episode (AT, $\mathrm{f}_{\text {temp }}$ in Fig. 3). Differences between measured and modelled SWP values for SPO site in SK-HTMts (Fig. 5) show relatively good agreement when we take into account threshold limits (SWP max-SWP min) as well as $\mathrm{f}_{\text {swP. }}$. Due to the absence of field SWP measurement, the comparison with the modelled data is not presented for RCS in FR-AlpMar. For future work, it should be beneficial to include SWP data from field measurement into MOD modelling, especially for areas with soil water deficit such as FR-AlpMar.
The relevance of $\mathrm{f}_{\text {swP }}$ in relation to model outputs of $\mathrm{F}_{\text {st }}$ and MOD [Eq. 1-2] demonstrate Fig. 6 with nearly two

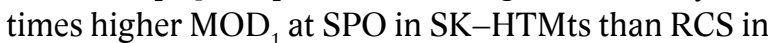
FR-AlpMar, considering theoretical $\mathrm{c}\left(\mathrm{z}_{1}\right)=1 \mathrm{ppb}$.

\subsection{Ozone concentration and ozone dose}

The measurement of $\mathrm{O}_{3}$ concentration at SPO using the active ozone monitor equipment suggests relatively high $\mathrm{O}_{3}$ abundance in the subalpine zone SK-HTMts with a mean annual value of $45.9 \mathrm{ppb}$ (2000-2019). It can be assumed that $\mathrm{O}_{3}$ formation at this site depends on the complex actions of $\mathrm{O}_{3}$ precursors originated from various sources (local, regional, from long-distance transport, anthropogenic, biogenic). Measured $\mathrm{O}_{3}$ concentration recalculated to reference height of $20 \mathrm{~m}$ (ICP, 2016) refers to nearly two times higher average $\mathrm{O}_{3}$ values for SPO ( $>50 \mathrm{ppb})$ than RCS site ( $>25 \mathrm{ppb})$ during the summer season from June to August 2019 (Fig. 7 left). Standard model processing input $\mathrm{O}_{3}$ data in the hourly step resulted in the value of MOD close below $15 \mathrm{mmol} \mathrm{m}^{-2}$ PLA (Fig. 7 right) at SPO in SK-HTMts. Modified calculation linking to $\mathrm{MOD}_{\mathrm{m}}$ value shows good agreement with MOD (Table 2, Fig. 8). Modification approach asso- 

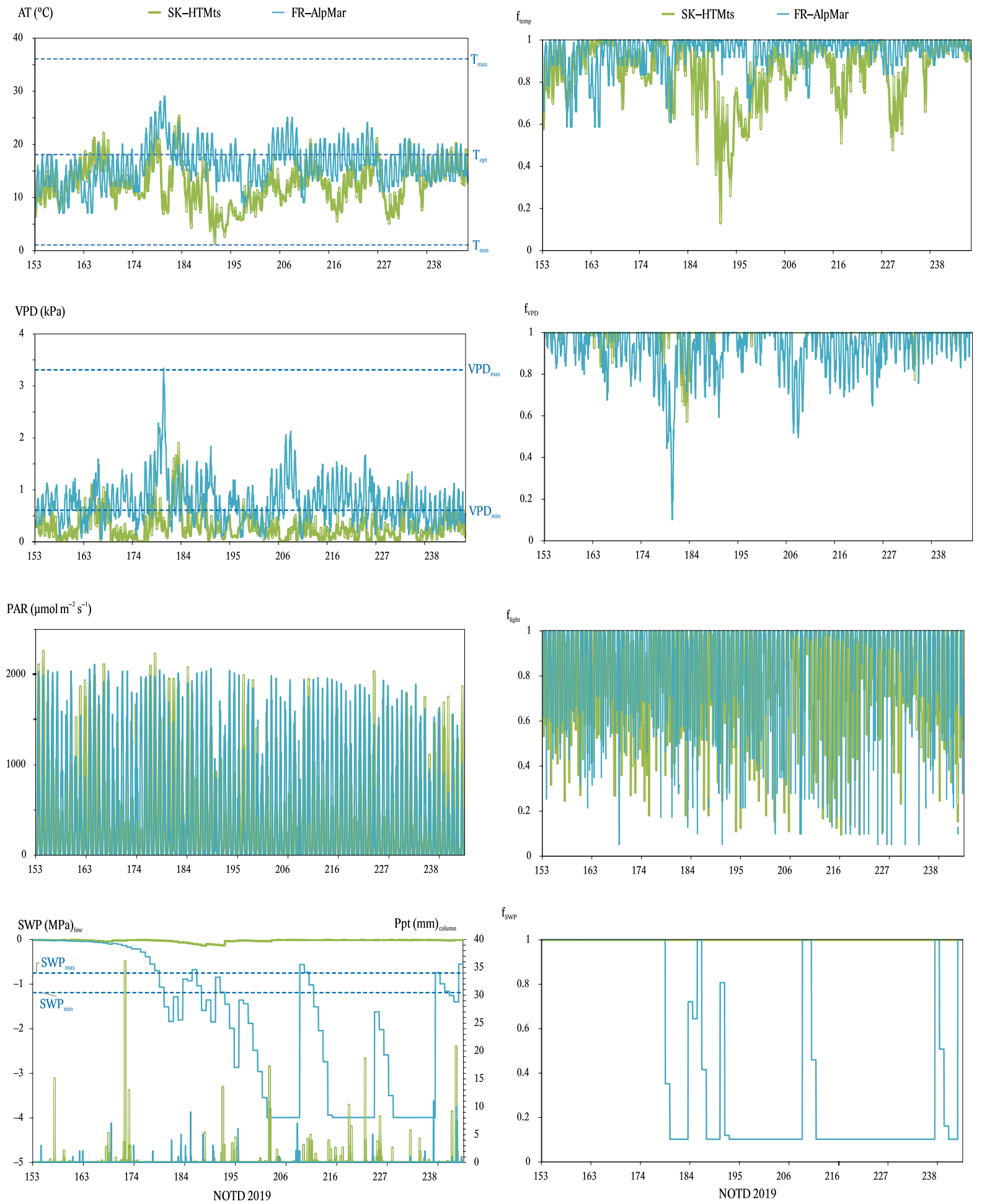

Fig. 3. Seasonal development of hourly measured meteorological data (left part) and corresponding environmental factors (right part) processed by $\mathrm{DO}_{3} \mathrm{SE}$ model for SK-HTMts and FR-AlpMar sites. 

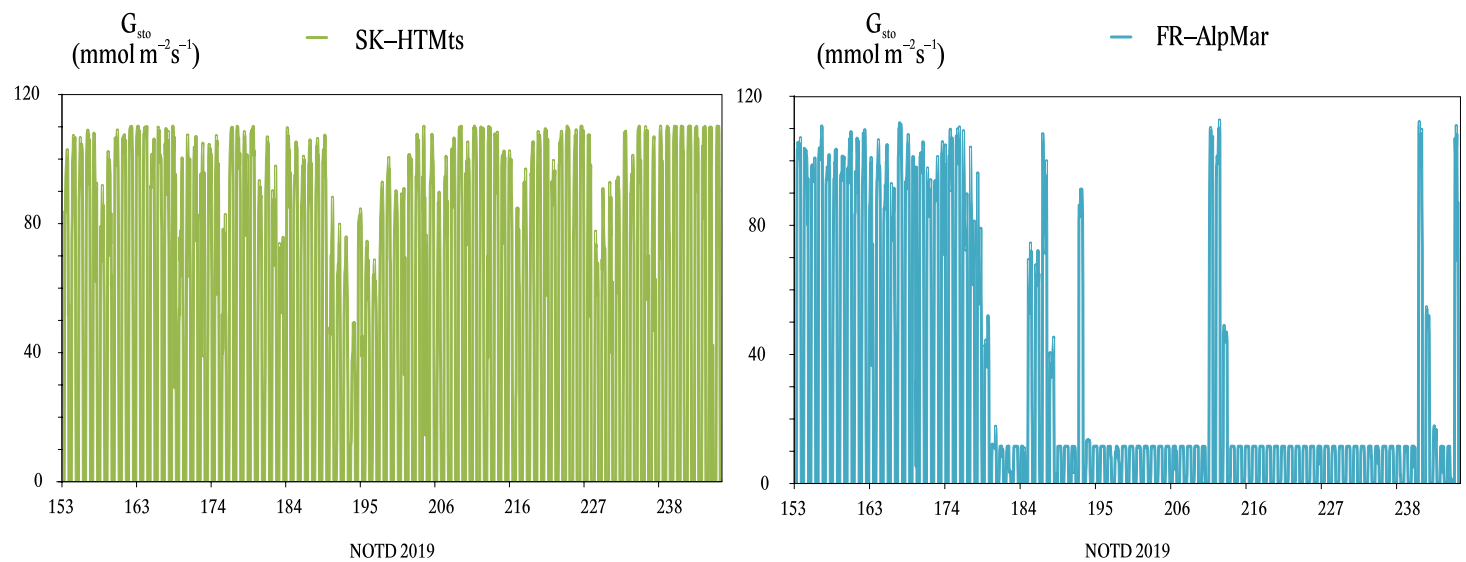

Fig. 4. Model results of $\mathrm{G}_{\text {sto }}$ processed by $\mathrm{DO}_{3} \mathrm{SE}$ model for SK-HTMts and FR-AlpMar sites.

ciated with the value of $\mathrm{MOD}_{\mathrm{m}}$ consists of multiplying of model $\mathrm{MOD}_{1}$ output for theoretical $\mathrm{O}_{3}$ concentration $\mathrm{c}\left(\mathrm{z}_{1}\right)=1 \mathrm{ppb}$ and $\mathrm{O}_{3}$ concentration averaged over considering periodi.e. $\mathrm{c}(\mathrm{z} 1)=\mathrm{O}_{3}$ avg $(\mathrm{ppb})$. This approach was used to estimate MOD at RCS in FR-AlpMar where only monthly $\mathrm{O}_{3}$ data obtained by passive samplers are avail-

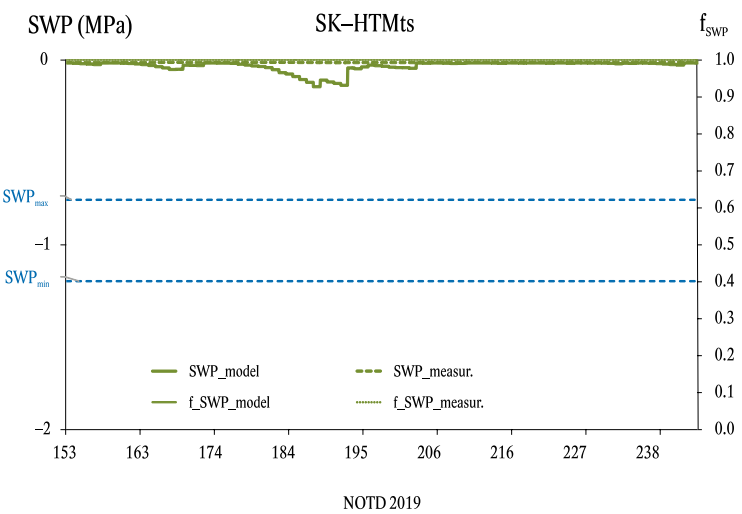

Fig. 5. Measured hourly values of SWP at SPO site in SK-HTMts in comparison with model results of SWP and $f_{\text {SWP }}$.

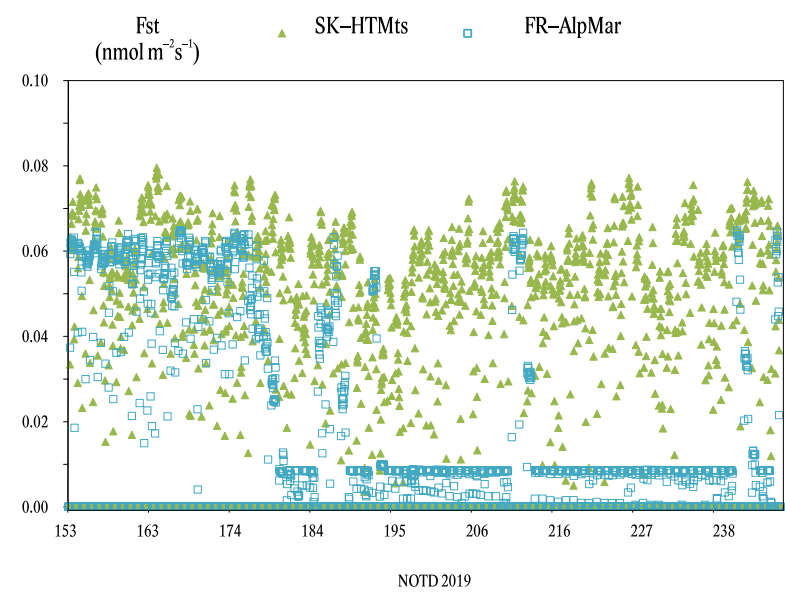

able. For this site, the average value $\mathrm{c}\left(\mathrm{z}_{1}\right)$ was $32.3 \mathrm{ppb}$ (Table 2) in the period JJA 2019. According to achieved MOD outputs, we can assume that P. mugo in SK-HTMts absorbed substantially higher $\mathrm{O}_{3}$ amount $(\mathrm{MOD}=$ $14.1 \mathrm{mmol} \mathrm{m}^{-2} \mathrm{PLA} \approx \mathrm{MOD}_{\mathrm{m}}$ ) than P. cembra in FRAlpMar $\left(\mathrm{MOD}_{\mathrm{m}}=4.0 \mathrm{mmol} \mathrm{m}^{-2} \mathrm{PLA}\right)$ during the same time period JJA 2019.

\subsection{Visible injury}

Foliar ozone specific injury observed on the surface of P. cembra needles at RCS plot in FR-AlpMar in 2019 (Fig. 9), presented a percentage of deterioration of $3 \%$ (C), $16 \%(\mathrm{C}+1)$, and $25 \%(\mathrm{C}+2)$ on an average i.e. in a range from low to moderate damage (class 1-2). As expected, the symptom of mottling was most commonly observed on older needles. Mottling occurred as a small spot of yellow/light green or mottling with a diffuse outline, especially on the upper surface and at the tip of the needles. Despite the low MOD of $4.0 \mathrm{mmol} \mathrm{O}_{3} \mathrm{~m}^{-2}$ PLA (Table 2), the frequency of mottling identified on $P$. cembra $(\mathrm{C}+2)$ was markedly higher when comparing

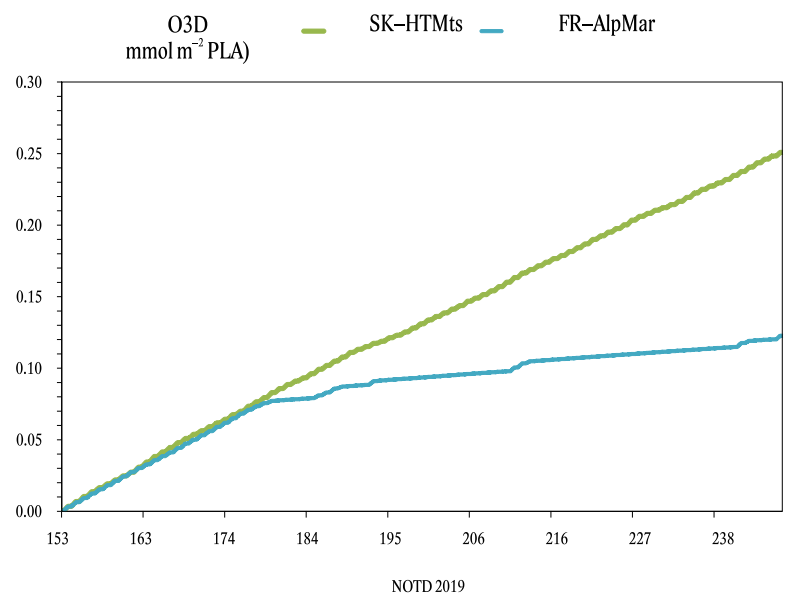

Fig. 6. Model results of stomatal ozone flux $\left(\mathrm{F}_{\mathrm{st}}\right.$, left) and modelled ozone dose $\left(\mathrm{MOD}_{1}\right.$, right) processed theoretical input $\mathrm{O}_{3}$ concentration $\mathrm{c}\left(\mathrm{z}_{1}\right)=1 \mathrm{ppb}$ for SK-HTMts and FR-AlpMar sites. 

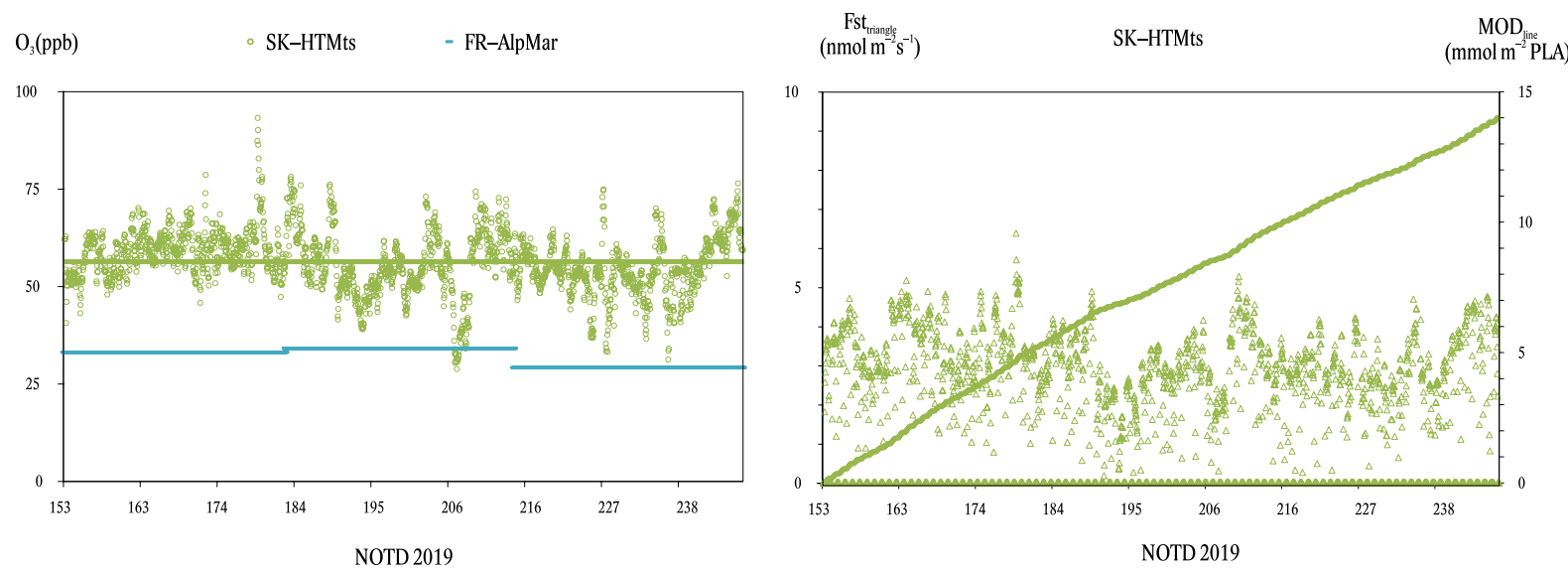

Fig. 7. Measured $\mathrm{O}_{3}$ concentration (left): long straight line depicts the average of hourly data obtained from active analyzer at SPO in SK-HTMts and short straight lines illustrate monthly averages derived from passive samples at RCS in FR-AlpMar; on right: standard model outputs $\mathrm{F}_{\text {st }}$ and MOD using real hourly $\mathrm{O}_{3}$ data from measurement at SPO in SK-HTMts; to estimate MOD value for RCS in FR-AlpMar requires modification approach.

Table 2. The MOD value based on hourly $\mathrm{O}_{3}$ data $\left(\mathrm{O}_{3}-\mathrm{h}\right)$ and MODm results linking to averaged $\mathrm{O}_{3}$ concentration $\left(\mathrm{O}_{3} \_\right.$avg $)$for JJA 2019 period.

\begin{tabular}{|c|c|c|c|c|c|}
\hline \multirow{2}{*}{ Study site } & \multirow{2}{*}{$\begin{array}{c}\text { MOD } \\
\text { mmol m}{ }^{-2} \text { PLA } \\
\mathrm{c}\left(\mathrm{z}_{1}\right) \\
\mathrm{O}_{3}-\mathrm{h}(\mathrm{ppb})\end{array}$} & \multicolumn{3}{|c|}{$\begin{array}{c}\mathrm{MOD}_{\mathrm{m}} \\
\mathrm{mmol} \mathrm{m}^{-2} \mathrm{PLA}\end{array}$} & \multirow{2}{*}{$\begin{array}{c}\text { MOD vs MOD } \\
\text { Difference (\%) }\end{array}$} \\
\hline & & $\mathrm{MOD}_{1}$ & $\begin{array}{c}c\left(z_{1}\right) \\
\mathrm{O}_{3}-a v g(p p b)\end{array}$ & $\begin{array}{c}\mathrm{MOD}_{1} \\
\mathrm{xO}_{3} \text {-avg }\end{array}$ & \\
\hline SK-HTMts & 14.0 & 0.25 & 56.2 & 14.1 & $0.7 \%$ \\
\hline FR-AlpMar & : & 0.12 & 32.3 & 4.0 & : \\
\hline
\end{tabular}

ozone symptoms evidenced on P. mugo (C+2) in Table 3. The rare incidence of visible $\mathrm{O}_{3}$ injury (VINX $=3 \%$ on an average, Class $=1$ ) suggests the tolerance of $P$. mugo in SK-HTMts towards MOD value of $14.1 \mathrm{mmol} \mathrm{O}_{3} \mathrm{~m}^{-2}$ PLA. On the other hand, low MOD associated with frequently mottling occurrence could denote a high sensitivity of $P$. cembra on ozone and environmental stress in FR-AlpMar.

Visible injury on $P$. mugo $(\mathrm{C}+2)$ needles in SK-HTMts represented by VINX (\%) confirm the increase of field sample damage from $14 \%$ at the beginning (June 2019) to $21 \%$ at the end of growing season (October 2019) on an average (VINX (a-e) in Table 3), which corresponds

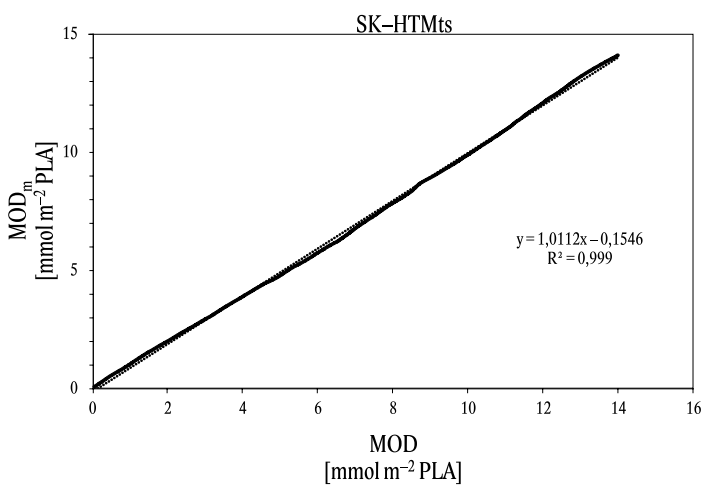

Fig. 8. Correlation between MOD corresponding to the input of $\mathrm{O}_{3}$ concentration measured in hourly step and $\mathrm{MOD}_{\mathrm{m}}$ based on $\mathrm{O}_{3}$ concentration averaged over JJA 2019 period at site SPO in SK-HTMts. to class 2 (i.e. Moderate injury) based on Table 1. corresponds $\operatorname{VINX}(\mathrm{a}, \mathrm{b}, \mathrm{c}, \mathrm{d}, \mathrm{e})$ differentiated according to the type of harmful agent accents similarity to the incidence of $\mathrm{O}_{3}$ symptoms and injury due to fungi diseases or biting

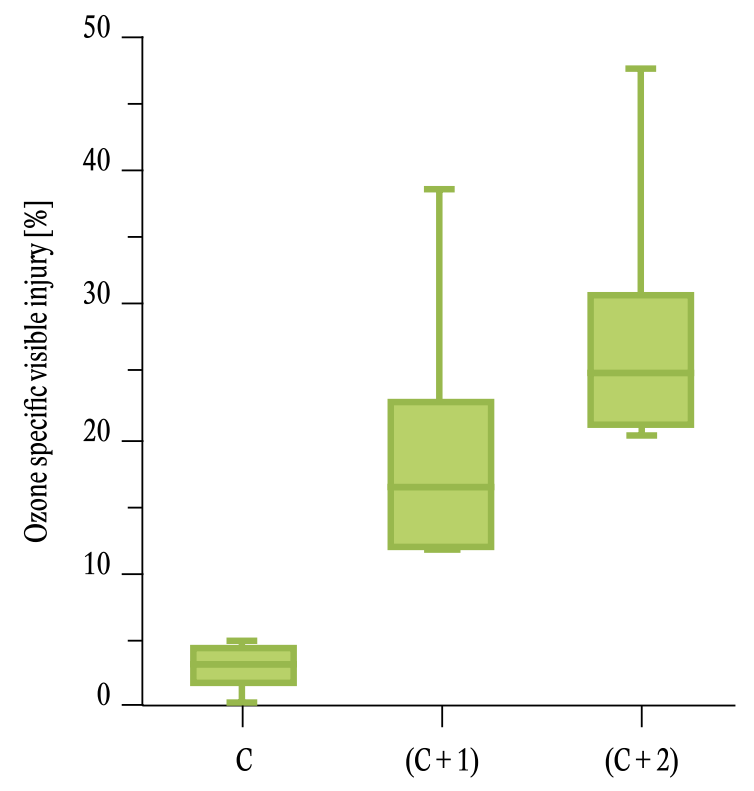

Fig. 9. Box-whiskers statistic plot shows foliar ozone specific injury on P. cembra at RCS site in FR-AlpMar for different-aged needles: current year $(C)$, one year old $(C+1)$, and two years old $(C+2)$ inspected in 2019. For each box-whisker plot, the center dot represents the average of the foliar injury during the study period. 
Table 3. Inspection of visible injury on P. mugo $(\mathrm{C}+2)$ needles in SK-HTMts at the beginning (June) and the end (October) of the growing season 2019.

\begin{tabular}{|c|c|c|c|c|c|c|c|c|c|}
\hline \multirow{3}{*}{\multicolumn{2}{|c|}{$\begin{array}{l}\text { June/October } \\
2019\end{array}$}} & \multicolumn{5}{|c|}{ Score: 0 (without injury) 5 (extensive damage) } & \multirow{3}{*}{$\begin{array}{l}\text { (a-e) } \\
\text { Score } \\
\text { sum }\end{array}$} & \multirow{3}{*}{$\begin{array}{c}(\mathrm{a}-\mathrm{e}) \\
\text { VINX \% }\end{array}$} & \multirow{3}{*}{$\begin{array}{l}(\mathrm{a}-\mathrm{e}) \\
\text { Class }\end{array}$} \\
\hline & & \multirow{3}{*}{$\begin{array}{c}(\mathrm{a}) \\
\text { Fungi diseases } \\
0 / 0\end{array}$} & \multirow{3}{*}{$\begin{array}{c}\text { (b) } \\
\text { Biting insects } \\
0 / 0\end{array}$} & \multirow{3}{*}{$\begin{array}{c}\text { (c) } \\
\text { Spider mites } \\
1 / 1\end{array}$} & \multirow{3}{*}{$\begin{array}{c}(\mathrm{d}) \\
\text { Ozone mottles } \\
0 / 0\end{array}$} & \multirow{3}{*}{$\begin{array}{c}(\mathrm{e}) \\
\text { Abiotic traces } \\
0 / 1\end{array}$} & & & \\
\hline & & & & & & & & & \\
\hline \multirow{25}{*}{$\begin{array}{l}\frac{\mathscr{3}}{5} \\
\frac{0}{0} \\
\frac{0}{2}\end{array}$} & & & & & & & \multirow{4}{*}{$4 / 9$} & \multirow{4}{*}{$5 / 12$} & \\
\hline & \multirow[t]{3}{*}{ S1 } & $0 / 0$ & $0 / 0$ & $0 / 1$ & $1 / 0$ & $0 / 1$ & & & \multirow[t]{3}{*}{$1 / 2$} \\
\hline & & $0 / 2$ & $1 / 1$ & $1 / 1$ & $0 / 0$ & $0 / 1$ & & & \\
\hline & & $0 / 1$ & $0 / 0$ & $1 / 1$ & $0 / 0$ & $0 / 1$ & & & \\
\hline & \multirow[t]{3}{*}{ S2 } & $1 / 1$ & $2 / 2$ & $1 / 1$ & $1 / 0$ & $0 / 3$ & \multirow[t]{3}{*}{$11 / 14$} & \multirow[t]{3}{*}{$15 / 19$} & \multirow[t]{3}{*}{$2 / 2$} \\
\hline & & $0 / 1$ & $1 / 1$ & $2 / 1$ & $2 / 0$ & $0 / 1$ & & & \\
\hline & & $1 / 1$ & $1 / 1$ & $1 / 1$ & $1 / 1$ & $0 / 2$ & & & \\
\hline & \multirow[t]{3}{*}{ S3 } & $0 / 0$ & $1 / 1$ & $1 / 1$ & $0 / 1$ & $0 / 1$ & \multirow[t]{3}{*}{$10 / 17$} & \multirow[t]{3}{*}{$13 / 23$} & \multirow[t]{3}{*}{$2 / 2$} \\
\hline & & $0 / 1$ & $1 / 2$ & $2 / 1$ & $1 / 1$ & $0 / 2$ & & & \\
\hline & & $2 / 1$ & $0 / 0$ & $1 / 2$ & $1 / 1$ & $0 / 2$ & & & \\
\hline & \multirow[t]{3}{*}{ S4 } & $1 / 1$ & $0 / 1$ & $2 / 2$ & $0 / 1$ & $0 / 3$ & \multirow[t]{3}{*}{$14 / 23$} & \multirow[t]{3}{*}{$19 / 31$} & \multirow[t]{3}{*}{$2 / 2$} \\
\hline & & $1 / 0$ & $1 / 0$ & $3 / 3$ & $2 / 2$ & $0 / 4$ & & & \\
\hline & & $1 / 1$ & $1 / 2$ & $1 / 2$ & $1 / 1$ & $0 / 1$ & & & \\
\hline & S5 & $1 / 1$ & $0 / 1$ & $2 / 2$ & $0 / 2$ & $0 / 1$ & $12 / 22$ & $16 / 29$ & $2 / 2$ \\
\hline & & $1 / 1$ & $2 / 2$ & $1 / 2$ & $1 / 2$ & $0 / 1$ & & & \\
\hline & & $0 / 1$ & $0 / 0$ & $1 / 2$ & $0 / 1$ & $0 / 1$ & & & \\
\hline & S6 & $4 / 0$ & $1 / 0$ & $2 / 1$ & $0 / 0$ & $0 / 1$ & $10 / 9$ & $13 / 12$ & $2 / 2$ \\
\hline & & $0 / 0$ & $0 / 0$ & $1 / 1$ & $1 / 0$ & $0 / 1$ & & & \\
\hline & S7 & $1 / 1$ & $0 / 0$ & $2 / 1$ & $1 / 1$ & $0 / 1$ & & & \\
\hline & S8 & $1 / 1$ & $0 / 0$ & $1 / 1$ & $1 / 1$ & $3 / 1$ & $19 / 23$ & $19 / 23$ & $2 / 2$ \\
\hline & S9 & $1 / 1$ & $1 / 0$ & $1 / 2$ & $1 / 1$ & $0 / 1$ & & & \\
\hline & S10 & $2 / 2$ & $0 / 1$ & $2 / 2$ & $1 / 2$ & $0 / 3$ & & & \\
\hline & Sum & $18 / 18$ & $13 / 15$ & $30 / 32$ & $16 / 18$ & $3 / 34$ & $80 / 117$ & : & : \\
\hline & $(a, b, c, d, e) \operatorname{VINX}(\%)$ & $3 / 3$ & $2 / 3$ & $5 / 6$ & $3 / 3$ & $1 / 6$ & : & $14 / 21$ & : \\
\hline & Class & $1 / 1$ & $1 / 1$ & $1 / 2$ & $1 / 1$ & $1 / 2$ & : & : & $2 / 2$ \\
\hline & & $1 / 1$ & $0 / 0$ & $1 / 1$ & $0 / 0$ & $0 / 0$ & & & \\
\hline$\cong$ & K0 & $0 / 0$ & $0 / 0$ & $1 / 0$ & $0 / 0$ & $0 / 1$ & $4 / 3$ & $5 / 4$ & $1 / 1$ \\
\hline के & & $0 / 0$ & $0 / 0$ & $1 / 0$ & $0 / 0$ & $0 / 0$ & & & \\
\hline 荥 & Sum & $1 / 1$ & $0 / 0$ & $3 / 1$ & $0 / 0$ & $0 / 1$ & $4 / 3$ & : & : \\
\hline$\overline{3}$ & VINX \% & $1 / 1$ & $0 / 0$ & $4 / 1$ & $0 / 0$ & $0 / 1$ & : & $5 / 4$ & $:$ \\
\hline & Class & $1 / 1$ & $0 / 0$ & $1 / 1$ & $0 / 0$ & $0 / 1$ & : & $:$ & $1 / 1$ \\
\hline
\end{tabular}

insects. Although spider mites symptoms dominated in the biotic agent group in June as well as in October 2019, deterioration during the growing season was particularly due to abiotic/mechanical type of damage. The inspection of the control plants situated in a protected indoor environment revealed low injury up to $5 \%$ i.e. class 1 (Table 1), primarily due to the occurrence of spider mites. We did not notice deterioration, contrary; improving concerning the occurrence of spider mites suggests high regeneration ability of $P$. mugo seedlings.

\section{Discussion}

Commonly used methods for assessing the impact of ozone on forests are based on the measurement of $\mathrm{O}_{3}$ concentration (AOT40) and modelling of accumulated stomatal $\mathrm{O}_{3}$ flux (POD) that provide AQI generally related to the abiotic element of the environment. On the other hand, the core of the $\mathrm{O}_{3}$ phytotoxicity problem lies in the disruption of the biological integrity of plant cells due to oxidative stress. The major challenge in the development of $\mathrm{O}_{3}$ standards is their validation against biologicallybased field data (Paoletti \& Manning 2007). Specific ozone visible symptoms are still the best indicator of ozone induced injury (Sicard \& Dalstein-Richier 2015; Paoletti et al. 2019). In this work, we present results of visible $\mathrm{O}_{3}$ injury inspection undertaken on $P$. cembra in FR-AlpMar and P. mugo in SK-HTMts. The inspection of visible injury on $P$. mugo highlights the importance of complex evaluation of all biotic and abiotic agents oper- ating in mountainous zones beside the $\mathrm{O}_{3}$ symptoms (Table 3). Ozone may have an impact on discoloration and defoliation and should be considered together with the influence of other factors (Badea et al. 2004).

Although substantially different MOD values (Table 2 ), relatively low incidence of $\mathrm{O}_{3}$ symptoms suggests milder $\mathrm{O}_{3}$ effect on $P$. mugo in SK-HTMts than on $P$. cembra in FR-AlpMar (Table 2). The presence of foliar visible symptoms can be interpreted as a strategy of Pinus species adapted to limiting environmental conditions and does not mean necessarily damage resulting in growing reduction (Marzuoli et al. 2019). The discrepancy between a low value of VINX (Table 3) and a high level of MOD (Table 2) related to P. mugo in SK-HTMts could be associated e. $\mathrm{g}$. with the activation of antioxidant enzymes in the needles acclimating to increased levels of oxidative stress. Superoxide dismutase enzymes (SODs) concentrations typically increase with the degree of stress conditions. SODs act as antioxidants and protect cellular components from being oxidized when catalyzing the production of $\mathrm{O}_{2}$ and $\mathrm{H}_{2} \mathrm{O}_{2}$ from superoxide $\left(\mathrm{O}^{2-}\right)$ (Alscher et al. 2002). High levels of SOD activity could protect the plant from visible injury caused by ozone when the overproduction of SOD in the chloroplasts may result in a 3-4 fold reduction of visible $\mathrm{O}_{3}$ injury (Van Camp et al. 1994). Kormuták et al. (2019) found the increasing content of SOD in the P. mugo needles in High Tatra Mts. from April, with the peak in August, followed by a slow decrease until November. 
The phytotoxic effect of ozone on Pinus species we investigated by tracing biological symptoms such as visible $\mathrm{O}_{3}$ injury in relationship to MOD. The amount of ozone absorbed by forest trees can be estimated by modelling that requires precise and continual field measured input data supplemented by species-specific model parameters. To achieve more accurate results of MOD in FR-AlpMar, measurements of input data should be realized within selected forest plots in hourly step using automatic types of equipment both for meteorological variables and $\mathrm{O}_{3}$ concentration. On the other hand, to obtain uninterrupted hourly $\mathrm{O}_{3}$ data based on active $\mathrm{O}_{3}$ monitor measurement in mountain field conditions is difficult. Passive sensors providing $\mathrm{O}_{3}$ concentration averaged over a month period seem operationally more friendly than the active monitors. In that context, it would be appropriate to arrange the $\mathrm{O}_{3}$ measurement that consists of at least one point equipped by both the active monitor and passive sensor with additional points at remote plots using passive sensors. Substitution of measured hourly $\mathrm{O}_{3}$ concentrations by average $\mathrm{O}_{3}$ concentration over the growing season period for calculation MOD (Fig. 8) is possible for plots situated in a subalpine zone with the typical flattened daily course due to the nondestruction of ozone at night. It follows that average $\mathrm{O}_{3}$ values derived from passive samplers could be used in MOD modelling although there is a study referring to the differences between active and passive $\mathrm{O}_{3}$ sampling that can range for e.g. from $-14 \%$ to $77 \%$ when comparing seasonal mean $\mathrm{O}_{3}$ concentrations (Pitar et al. 2018). Model results of SWP, as well as $\mathrm{f}_{\mathrm{SWP}}$, revealed a relevant decrease of $G_{\text {sto }}$ as a response to soil moisture deficit in summer season in FR-AlpMar (Fig. 4). Soil moisture conditions can have a significant effect on stomatal conductance (De Marco et al. 2016). Field measurement of SWP is important to take into account when modelling the stomatal $\mathrm{O}_{3}$ flux especially in areas where soil drought events in association with lower precipitation occurs.

For the future, the system of air quality with respect to the biological response of mountain tree species to $\mathrm{O}_{3}$ could be innovated by introducing modern methods providing the opportunity to analyze large areas e.g. employing the remotely sensed satellite data and spectral indices.

\section{Conclusion}

Respecting the objectives of this study, research of Pinus species response to ozone pollution suggests that $P$. mugo in SK-HTMts received substantially higher ozone dose than P. cembra in FR-AlpMar during considering period JJA 2019. Relatively low MOD uptaken by P. cembrawas particularly due to soil drought linking to fSWP factor. This confirms our assumption that hot, sunny, and dry summer weather typical for the Mediterranean climate plays the principal role in ozone uptake. Despite the low MOD, a high degree of surface damage on two years old needles of $P$. cembra was identified. This may indicate high sensitivity $P$. cembra to ozone and environmental stress. On the other hand, although high MOD, an inspection of visible $\mathrm{O}_{3}$ injury on $P$. mugo showed a low incidence of $\mathrm{O}_{3}$ symptoms on $P$. mugo needles surface in SK-HTMts. This may be associated with the activation of antioxidant enzymes under oxidative stress conditions. In this work, we also tested the use of passive $\mathrm{O}_{3}$ sampler measurements in the model simulation of MOD. Our results present that the average $\mathrm{O}_{3}$ concentration for the considered period can replace $\mathrm{O}_{3}$ concentration in an hourly step in the model input file, primarily for field sites situated in the subalpine and alpine zone where nearly flat daily $\mathrm{O}_{3}$ course is observed.

\section{Acknowledgement}

This research has been supported financially by the Alcotra program MITIMPACT (Grant number, 1671/ 1450109240) and technically by the staffs of Mercantour National Park. We are grateful to all members of the technical staff of the Earth Science Institute of the Slovak Academy of Science and Slovak Hydrometeorological Institute for the data they measure at Skalnate Pleso Observatory. This work was supported also by the Scientific Grant Agency of the Slovak Republic, VEGA project No. 2/0015/18 and by the Slovak Research and Development Agency under the contract No. APVV-16-0325. The development of the $\mathrm{DO}_{3} \mathrm{SE}$ model interface has been made possible through funding provided by the UK Department of Environment, Food, and Rural Affairs (DEFRA) and through institutional support provided to the Stockholm Environment Institute from the Swedish International Development Agency (SIDA).

\section{References}

Alscher, R. G., Erturk, N., Heath, L. S., 2002: Role of superoxide dismutase (SODs) in controlling oxidative stress in plants. Journal of Experimental Botany, 53:1331-1341.

Analitis, A., De' Donato, F., Scortichini, M., Lanki, T., Basagana, X., Ballester, F. et al., 2018: Synergistic Effects of Ambient Temperature and Air Pollution on Health in Europe: Results from the PHASE Project. International Journal of Environmental Research and Public Health, 15:1856.

Ashmore, M., Emberson, L., Karlsson, P. E., Pleijel, H., 2004: New Directions: A new generation of ozone critical levels for the protection of vegetation in Europe. Atmospheric Environment, 38:2213-2214.

Badea, O., Tanase, M., Georgeta, J., Anisoara, L., Peiov, A., Uhlirova, H. et al., 2004: Forest health status in the Carpathian Mountains over the period 1997-2001. Environmental Pollution, 130:93-98.

Bendáková, H., Hůnová, I., 2015: Surface as one of several oxidative stress factors in mountain forests. (in Czech language). Meteorologické zprávy-Meteorological Journal, 68:8-17. 
Bičárová, S., Sitková, Z., Pavlendová, H., Fleischer, P., Bytnerowicz, A., 2019: The role of environmental factors in ozone uptake of Pinus mugo Turra. Atmospheric Pollution Research, 10:283-293.

Braun, S., Schindler, C., Rihm, B., 2014: Growth losses in Swiss forests caused by ozone: Epidemiological data analysis of stem increment of Fagus sylvatica L. and Picea abies Kars. Environmental Pollution, 192:129-138.

Büker, P., Morrissey, T., Briolat, A., Falk, R., Simpson, D., Tuovinen, J.-P. et. al., 2012: $\mathrm{DO}_{3}$ SE modelling of soil moisture to determine ozone flux to forest trees. Atmospheric Chemistry and Physics, 12:5537-5562.

Bytnerowicz, A., Godzik, B., Grodzińska, K., Fraączek, W., Musselman, R., Manning, W. et al., 2004: Ambient ozone in forests of the Central and Eastern European mountains. Environmental Pollution, 130:5-16.

Coulston, J. W., Smith, G. C., Smith, W. D., 2003: Regional Assessment of Ozone Sensitive Tree Species Using Bioindicator Plants. Environmental Monitoring and Assessment, 83:113-127.

Dalstein, L., Teton, S., Cottereau, C., Vas, N., 2001: Niveaux d'ozone et endommagement foliaire sur quelques essences méditerranéennes. Pollution Atmosphérique, 170:263-277.

Dalstein-Richier, L., Mangin, A., Carréga, P., Gueguen, C., Vas, N., Sanchez, O. et al., 2005: B. Théodore, W. Bérolo État des forêts d'altitude en relation avec la pollution de l'air par l'ozone dans la région niçoise. Pollution Atmosphérique, 188:503-519.

Dalstein, L., Vas, N., 2005: Ozone Concentrations and Ozone-Induced Symptoms On Coastal and Alpine Mediterranean Pines in Southern France. Water, Air, and Soil Pollution, 160:181-195.

De Marco, A., Sicard, P., Fares, S., Tuovinen, J-P., Anav, A., Paoletti, E., 2016: Assessing the role of soil water limitation in determining the Phytotoxic Ozone Dose $\left(\mathrm{POD}_{\mathrm{Y}}\right)$ thresholds. Atmospheric Environment, 147:88-97.

Dizengremel, P., Jolivet, Y., Tuzet, A., Ranieri, A., Le Thiec, D., 2013: Integrative Phytotoxic Ozone Dose Assessment in Leaves in View of Risk Modelling for Forest Ecosystems. In: R. Matyssek, N. Clarke, P. Cudlin, T. N. Mikkelsen, J.-P. Tuovinen G. Wieser, E. Paoletti (eds.): Climate Change, Air Pollution and Global Challenges: Knowledge, Understanding and Perspectives from Forest Research, Elsevier Physical Sciences Series "Developments in Environmental Science”, 13:267-283.

Feng, Z.Z., Büker, P., Pleijel, H., Emberson, L. D., Karlsson, P. E., Uddling, J., 2017: A unifying explanation for variation in ozone sensitivity among woody plants. Global Change and Biology, 24:1-7.
Fleischer, P., Pichler, V., Fleischer, Jr., P., Holko, L., Máliš, F., Gömöryová, E. et al., 2017: Forest ecosystem services affected by natural disturbances, climate and land-use changes in the Tatra Mountains. Climate Research, 73/1:1-15.

Gong, C., Lei, Y., Ma, Y., Yue, X., Liao, H., 2020: Ozonevegetation feedback through dry deposition and isoprene emissions in a global chemistry-carbon-climate model. Atmospheric Chemistry and Physics, 20:3841-3857.

Hůnová, I., Novotný, R., Uhlířová, H., Vráblík, T., Horálek, J., Lomský, B. et al., 2010: The impact of ambient ozone on mountain spruce forests in the Czech Republic as indicated by malondialdehyde. Environmental Pollution, 158:2393-2401.

Jordan, D. N., Smith, W. K., 1993: Simulated influence of leaf geometry on sunlight interception and photosynthesis in conifer needles. Tree Physiology, 13:29-39.

Kopáček, J., Kaňa, J., Bičárová, S., Fernandez, I. J., Hejzlar, J., Kahounová, M. et al., 2017: Climate change increasing calcium and magnesium leaching from granitic Alpine catchments. Environmental Science and Technology, 51/1:159-166.

Kormuták, A., Galgóci, M., Boleček, P., Gömöry, D., 2019: Antioxidant enzyme activity in Pinus mugo Turra, $P$. sylvestris L. and in their putative hybrids. In Biologia, 74:631-638.

Krupa, S. V., Legge, A. H, 2000: Passive sampling of ambient, gaseous air pollutants: an assessment from an ecological perspective. Environmental Pollution, 107:31-45.

Marzuoli, R., Gerosa, G., Bussotti, F., Pollastrini, M., 2019: Assessing the Impact of Ozone on Forest Trees in An Integrative Perspective: Are Foliar Visible Symptoms Suitable Predictors for Growth Reduction? A Critical Review. Forests, 10:1144.

Matyssek, R., Bytnerowicz, A., Karlsson, P. E., Paoletti, E., Sanz, M., Schaub, M. et al., 2007: Promoting the $\mathrm{O}_{3}$ flux concept for European forest trees. Environmental Pollution, 146:587-607.

Meteoblue, 2019: History \& Climate, Climate (modelled). Available on https://www.meteoblue.com/en/weather/historyclimate/ climatemodelled/44.128N7.254E

Mezei, P., Jakuš, R., Pennerstorfer, J., Havašová, M., Škvarenina, J., Ferenčík, J. et al., 2017: Storms, temperature maxima and the Eurasian spruce bark beetle Ips typographus - An infernal trio in Norway spruce forests of the Central European High Tatra Mountains. Agricultural and Forest Meteorology, 242:85-95.

Michel, A., Seidling, W., Lorenz, M., Becher, G., 2014: Forest condition in Europe: 2013 technical report of ICP forests. In: Report under the UNECE Convention on Long-range Transboundary Air Pollution. Thünen Working Paper 19. 
Mills, G., Pleijel, H., Braun, S., Büker, P., Bermejo, V., Calvo, E. et al., 2011: New stomatal flux-based critical levels for ozone effects on vegetation. Atmospheric Environment, 45:5064-5068.

Nunn, A. J., Wieser, G., Metzger, U., Löw, M., Wipfler, P., Häberle, K.-H. et al., 2007: Exemplifying wholeplant ozone uptake in adult forest trees of contrasting species and site conditions. Environmental Pollution, 146:629-639.

Orru, H., Åström, C., Andersson, C., Tamm, T., Ebi, K. L, Forsberg, B., 2019: Ozone and heat-related mortality in Europe in 2050 significantly affected by changes in climate, population and greenhouse gas emission. Environmental Research Letters, 14:074013, doi: 10.1088/1748-9326/ab1cd9.

Paoletti, E., Manning, W. J., 2007: Toward a biologically significant and usable standard for ozone that will also protect plants. Environmental Pollution, 150:85-95.

Paoletti, E., Alivernini, A., Anav, A., Badea, O., Carrari, E., Chivulescu, S. et al., 2019: Toward stomatal-flux based forest protection against ozone: The MOTTLES approach. Science of the Total Environment, 691:516-527.

Pitar, D., Popa, I., Leca, S., Badea, O., 2018: Passive vs. active: Applicability of Loibl function in modeling hourly ozone concentrations from passive samplers in Romanian Intensive Monitoring Network. In International conference on ozone and plant ecosystem, 21-25 may, 2018. Florence: ICP Vegetation, 32 p.

Schaub, M., Calatayud, V., Ferretti, M., Brunialti, G., Lövblad, G., Krause, G. et al., 2010: Monitoring of ozone injury, manual part X. In: Manual on Methods and Criteria for Harmonized Sampling, Assessment, Monitoring and Analysis of the Effects of Air Pollution on Forests. UNECE ICP Forests Programme, Hamburg.

Schaub, M., Calatayud, V., Ferretti, M., Brunialti, G., Lövblad, G., Krause, G. Sanz, M. J., 2016: Part VIII: Monitoring of Ozone Injury. In: UNECE ICPForests Programme Co-ordinating Centre (ed.): Manual on methods and criteria for harmonized sampling, assessment, monitoring and analysis of the effects of air pollution on forests. Thünen Institute of Forest Ecosystems, Eberswalde, Available on http://www. icp-forests.org/manual.htm
Sicard, P., Dalstein-Richier, L., Vas, N., 2011: Annual and seasonal trends of ambient ozone concentration and its impact on forest vegetation in Mercantour National Park (South-eastern France) over the 20002008 period. Environmental Pollution, 159:351-362.

Sicard, P., Dalstein-Richier, L., 2015: Health and vitality assessment of two common pine species in the context of climate change in southern Europe. Environmental Research, 137:235-245.

Sicard, P., De Marco, A., Dalstein-Richier, L., Tagliaferro, F., Renou, C., Paoletti, E., 2016: An epidemiological assessment of stomatal ozone flux-based critical levels for visible ozone injury in Southern European forests. Science of the Total Environment, 541:729-741.

Van Camp, W., Willekens, H., Bowler, C., Van Montagu, M., Inzé, D., Langebartels, C. et al., 1994: Elevated levels of superoxide dismutase protect transgenic plants against ozone damage. Nature Biotechnology, 12: 165-168.

Zapletal, M., Pretel, J., Chroust, P., Cudlín, P., EdwardsJonášová, M., Urban, O. et al., 2012: The influence of climate change on stomatal ozone flux to a mountain Norway spruce forest. Environmental Pollution, 169:267-273.

\section{Other sources}

Directive 2008/50/EC of the European Parliament and of the Council of 21 May 2008 on ambient air quality and cleaner air for Europe.

EAQI, 2019: European Air Quality Index. Available on https://airindex.eea.europa.eu/Map/AQI/Viewer/

ICP, 2016: ICP Forest Executive report. Available on https://icp-forests.org/pdf/ER2016.pdf

ICP, 2017: Mapping Manual; Available on: www.icpmapping.org/Latest_update_Mapping_Manual.

ICP, 2018: Recording the presence/absence of ozone injury on Sensitive Ozone Species ('SOS') using the ICP Vegetation smart-phone App. Available on https://icpvegetation.ceh.ac.uk/sites/default/ files/ICPVegetation_OzoneGardensandAppprotocol_2018_Final.pdf

SEI, 2014: DO 3 SE (Deposition of ozone for stomatal exchange). Available on https://www.sei-international.org/do3se.

WAQI, 2019: World's Air Quality Index. Available on https://waqi.info/ 


\section{List of abbreviation}

\section{Study area}

SK

FR

SPO

RCS

\section{Ozone dose modelling}

$\mathrm{DO}_{3} \mathrm{SE}$

PODY $\left(\mathrm{nmol} \mathrm{m}^{-2} \mathrm{PLAs}^{-1}\right)$

$\operatorname{PLA}\left(\mathrm{m}^{-2}\right)$

POD0 $\left(\mathrm{nmol} \mathrm{m}^{-2} \mathrm{PLA} \mathrm{s}^{-1}\right)$

$\operatorname{MOD}\left(\mathrm{mmol} \mathrm{O} \mathrm{m}^{-2} \mathrm{PLA}\right)$

$\mathrm{MOD}_{\mathrm{m}}\left(\mathrm{mmolO}_{3} \mathrm{~m}^{-2} \mathrm{PLA}\right)$

$\mathrm{MOD}_{1}\left(\mathrm{mmol} \mathrm{O}_{3} \mathrm{~m}^{-2} \mathrm{PLA}\right)$

$\mathrm{c}\left(\mathrm{z}_{1}\right)$

$\mathrm{F}_{\mathrm{st}}\left(\mathrm{nmol} \mathrm{O}_{3} \mathrm{~m}^{-2} \mathrm{~s}^{-1}\right)$

$\mathrm{G}_{\mathrm{sto}}\left(\mathrm{mmol} \mathrm{O}_{3} \mathrm{~m}^{-2} \mathrm{~s}^{-1}\right)$

$\mathrm{G}_{\text {max }}^{\text {sto }}\left(\mathrm{mmolO}_{3} \mathrm{~m}^{-2} \mathrm{~s}^{-1}\right)$

$\mathrm{R}_{\mathrm{st}}-$ Resistance factor

$\mathrm{f}_{\mathrm{FNV}}$

AT $\left({ }^{\circ} \mathrm{C}\right)$

$\mathrm{T}_{\min }\left(1^{\circ} \mathrm{C}\right), \mathrm{T}_{\text {opt }}\left(18^{\circ} \mathrm{C}\right), \mathrm{T}_{\max }\left(36^{\circ} \mathrm{C}\right)$

RH (\%)

VPD $(\mathrm{kPa})$

$\mathrm{VPD}_{\text {min }}(-3.3 \mathrm{kPa}), \mathrm{VPD}_{\text {max }}(0.6 \mathrm{kPa})$

PFD $\left(\mu \mathrm{mol} \mathrm{m} \mathrm{m}^{-2} \mathrm{~s}^{-1}\right)$

$\operatorname{PAR}\left(\mu \mathrm{mol} \mathrm{m}^{-2} \mathrm{~s}^{-1}\right)$

$\mathrm{R}\left(\mathrm{W} \mathrm{m}^{-2}\right)$

light $_{\mathrm{a}}(0.008)$

$\mathrm{f}_{\text {light }}$

SWP (MPa)

SWPmin $(-1.20 \mathrm{MPa})$

$\operatorname{SWPmax}(-0.76 \mathrm{MPa})$

$f_{\text {sWP }}$

$f_{\text {phen }}$

$\mathrm{f}_{\text {min }}(0.1)$

SGS

EGS

$\mathrm{P}(\mathrm{kPa})$

Ppt (mm)

WS $\left(\mathrm{m} \mathrm{s}^{-1}\right)$
- HTMts: Slovakia, the High Tatra Mts.

- AlpMar: France, the Alpes-Maritimes region

- Skalnaté Pleso Observatory

- Route du Col de Salèse

- Multiplicative Deposition Model

- Phytotoxic Ozone Dose over a detoxification threshold flux of Y

- Projected Leaf Area

- Phytotoxic Ozone Dose without threshold limitation $(\mathrm{Y}=0)$

- Modelled Ozone Dose

- Modelled Ozone Dose Modified

- Modelled Ozone Dose for theoretical $\mathrm{O}_{3}$ concentr. $\mathrm{c}\left(\mathrm{z}_{1}\right)=1 \mathrm{ppb}$

$-\mathrm{O}_{3}$ concentration at the top of the canopy measured in the tree height $\left(\mathrm{z}_{1}\right)$

- Stomatal Ozone Flux

- Stomatal Conductance

- Maximal Stomatal Conductance

-Environmental factors

- Air Temperature

- Species-specific parameters of Air Temperature

- Factor of Air Temperature

- Relative Humidity

- Vapour Pressure Deficit

- Species-specific parameters of Vapour Pressure Deficit

- Factor of Vapour Pressure Deficit

- Photosynthetic photon Flux Density

- Photosynthetically Active Radiation

- Global Solar Radiation

- Species-specific parameters of Solar light

- Factor of Solar radiation or light

- Soil Water Potential

- Species-specific parameters of Soil Water Potential

- Species-specific parameters of Soil Water Potential

- Factor of Soil Water Potential

- Factor of Plant Phenology

- Species-specific parameter

- Start of Growing Season

- End of Growing Season

- Air Pressure

- Precipitation Amount

- Wind Speed

\section{Visible injury}

$\operatorname{VINX}(\%)$

- Visible Injury Index 